Crowley, N. (1954). J. gen. Microbiol. 10, 411-426.

\title{
On Amylolytic strains of Streptococcus pyogenes
}

\author{
BY NUALA CROWLEY \\ Bacteriology Department, Royal Free Hospital Medical School, London
}

SUMMARY: Strains of Streptococcus pyogenes belonging to Types 2 and 4 elaborated an amylolytic enzyme which was not usually a product of other serological Types though it was occasionally produced by members of Types 1, 9, 22 and Types related to 4, 5 and 25 . Sixty-six $\%$ of amylolytic strains were untypable by M precipitin tests.

The enzyme was produced by variants. Amylolytic organisms were generated by matt and large opaque colonies of the parent strains; small and glossy variants generated relatively fewer enzyme-positive cocci, and had often lost the amylolytic property. When studied as a single character in serial subcultures on starch agar, the property was transmissible, in some instances to $80 \%$ of the progeny for many generations (forty or more subcultures). Other strains readily lost the property in subculture on starch agar but recovered amylolytic power during passage on plasma agar in the absence of substrate. Certain amylolytic strains contained a trypsinresistant, serologically active substance which precipitated in anti-M, anti-T and anti-proteinase precursor serum. A similar substance diffused into the medium when strains were grown on agar containing the substrate. While serologically related to the cell antigen, the free substance was trypsin-sensitive.

Certain strains of Group A streptococci liberate an enzyme resembling $\alpha$-amylase (Crowley, 1950). The enzyme is usually found in culture-filtrates of Type 4 strains, which also produce hyaluronidase. The object of the present work was to determine the frequency of amylolytic strains among representative Types of Group A streptococci other than Type 4, already shown to produce $\alpha$-amylase (Crowley, 1950), and to study factors contributing to the spontaneously acquired amylolytic activity of single strains which did not belong to Type 4. This paper reports the frequency of amylolytic strains among 200 Group A streptococci in relation to serological Type ( $T$ and $M$ ). It also gives an account of observations made on amylolytic strains in relation to (1) amylolytic properties as a single character of variants, and (2) cellular and 'free' antigenic components of amylolytic cultures.

\section{MATERIALS AND METHODS}

Strains. Thirty stock cultures were received either from the Streptococcal Reference Laboratory, Colindale Avenue, N.W. 9 or from Dr R. C. Lancefield, Rockefeller Hospital, New York. Certain stock strains are named in the text. One hundred and seventy strains, 140 from England and 30 from the United States, were recently isolated when received in this laboratory. The majority of British strains were selected by the Streptococcal Reference Laboratory as single representatives of the one 'strain', namely a member of a serological Type causing infection in a particular region. In many instances several other representatives of one strain were also tested, but these are regarded as the 
same strain and are not included in the total number of 200. Twenty-eight strains from a single source, mentioned on p. 417, were received after the first part of the work was completed; these are not included in Tables 1-3.

Serological tests. Precipitin tests were carried out in capillary pipettes. Cell extracts for routine $\mathbf{M}$ typing were made by the method of Swift, Wilson \& Lancefield (1943). T antigen extracts were prepared by the method of Pakula (1951). Precipitating and agglutinating anti-sera were supplied by the Streptococcal Reference Laboratory: anti-M sera Types, 1, 2, 3, 4, 5, 6, 9, 12, 14, 15, 17, 18, 19, 23, 24, 26, 28, 29, 30. Anti-T agglutinating sera Types 1, 3, 13, B3264, 2, 4, 24, 26, 28, 29, 46, 6, 5, 11, 12, 27, 44, 14, 8, 25, Imp 19, 15, 17, $23,30,47,19,9,18$. The anti-sera were from batches usually issued for routine typing of streptococci by precipitation and agglutination, and were not specially absorbed. Both anti-M and anti-T sera may have contained either $\mathbf{M}, \mathbf{T}, \mathbf{R}$ or non-specific antibodies. Anti-M sera for Types 5, 12 and 14, and anti-T precipitating sera for Types 5 and 12 were specially absorbed with heterologous Type extracts. Proteinase-precursor anti-serum was supplied by Dr S. D. Elliott, Rockefeller Hospital, New York. All amylolytic strains, certain amylase negative strains and stock cultures were typed either by precipitin tests, or by slide agglutination (Griffith, 1934). Typing results for other amylase-negative strains were supplied by the Streptococcal Reference Laboratory. Cell extracts for serological grouping were prepared with lytic filtrates of Streptomyces sp. (Maxted, 1948).

Culture media. Agar base was prepared with Hartley digest broth, and the same base was used in blood agar, plasma agar and starch agar.

Plasma agar. Plasma agar contained pooled human plasma $(20 \%, \mathrm{v} / \mathrm{v}$, discarded from blood banks) and Fildes's peptic digest of sheep cells (2.5\%, $\mathrm{v} / \mathrm{v})$.

Starch agar. Starch agar ('minimal') contained soluble $\operatorname{starch}(1 \% \mathrm{w} / \mathrm{v}$, from freshly made gel) and Fildes's peptic digest $(2.5 \%, \mathrm{v} / \mathrm{v})$. Amioca (glutinous corn starch), which was also used in starch agar, was given by Messrs Brown and Polson, Wellington House, Strand, W. 2, or by the American Amaizo Company.

Broth cultures. Broth cultures for $\mathbf{M}$ and $\mathbf{T}$ typing were made in Neopeptone infusion broth (modified from Todd \& Hewitt, 1932) and in buffered peptone medium (Benger's peptone, $2 \% \mathrm{w} / \mathrm{v}$, in sterile tap water containing $\mathrm{NaCl}$, $0.5 \% \mathrm{w} / \mathrm{v}$, and sodium $\beta$-glycerophosphate, $2.5 \% \mathrm{v} / \mathrm{v})$. To obtain extra heavy growth of streptococci glucose $(0.1 \%, w / v)$ and Fildes's digest $(2.5 \%$, $\mathrm{v} / \mathrm{v}$ ) were also added. The $\mathrm{pH}$ value was adjusted to $7 \cdot 8$. Frozen and dried cultures were kept in brain-heart infusion (Difco).

Detection of amylase activity. Broth cultures or cell suspensions were seeded on starch agar to form growth in plaques. The inoculum was transferred with sterile capillary tubing or ' 50 -drop pipettes', which delivered a standard volume to form plaques about $1 \mathrm{~cm}$. in diameter. Six to nine cultures were seeded on one culture plate with an amylase-positive control strain for comparison. After overnight incubation at $37^{\circ}$, the homogeneity, opacity and amount of growth were recorded. Culture plates were then exposed to iodine 
vapour, and amylase-diffusion zones were indicated by achroic or dextrinized areas around the growth plaques. Doubtful and negative strains were retested by incubating culture plates for 2 or more days. Amylase-positive strains were streaked out on starch agar for several subcultures, and broth culture supernatants containing no substrate were titrated for amylase by iodometric assay (Crowley, 1950).

Proteolytic activity. Proteolytic activity was tested by the method of Elliott \& Dole (1947). In order to demonstrate the presence of the inactive proteinase precursor, culture supernatants were titrated for proteinase before and after incubation with (1) sodium mercaptoacetate $(0 \cdot 1 \mathrm{M})$ at $\mathrm{pH} 7 \cdot 0$ for $1 \mathrm{hr} ., 37^{\circ}$, and (2) crystalline trypsin (0.001 mg./ml.) at $\mathrm{pH} 8.0$ for $1 \mathrm{hr}$., $37^{\circ}$ (Elliott, 1950).

Trypsin sensitivity. Samples of antigenic material were incubated with crystalline trypsin $\left(0.01 \mathrm{mg}\right.$. $/ \mathrm{ml}$.) at $\mathrm{pH} 7.8$ for $6 \mathrm{hr}$. at $37^{\circ}$, and after sampling, the digests were re-incubated overnight.

Hyaluronidase production. Hyaluronidase production was assayed by the mucin clot-prevention test (McClean, 1942).

\section{EXPERIMENTAL}

Two hundred strains of Group A streptococci were grown on starch agar plates without enrichment other than Fildes's digest. Though not all strains grew well on the medium, it supported the growth of the majority. Certain strains which grew either poorly or indifferently were grown on starch agar prepared with Benger's peptone (2\%). All the strains were also grown on blood agar and plasma agar and the degree of haemolysis and the appearance of the colonies recorded. Amylolytic strains formed opaque growth on the 'minimal' starch agar, while the growth of amylase-negative strains was translucent. About half of the amylolytic strains formed homogeneous opaque cultures, but the remaining strains formed cultures in which large opaque colonies predominated, but small translucent colonies were visible through a hand-lens. A few strains gave rise to occasional large opaque amylolytic colonies which stood out against a background growth of translucent microcolonies. After exposure to iodine vapour amylolytic strains were easily classified as strongpositive, weak-positive or doubtful.

Strong-positive strains formed homogeneous opaque cultures with achroic zones of twice the diameter of the plaques, and in subcultures streaked out on starch agar, more than $80 \%$ of the colonies were enzyme-positive. The strains also liberated amylase in broth cultures in the absence of substrate, the titres ranging from 1/32 to $1 / 128$ by iodometric assay (Crowley, 1950). Weak-positive strains formed heterogeneous cultures, containing strong-positive, weakpositive and negative colonies. Some, but not all, weak-positive strains liberated amylase in broth cultures to a titre of $1 / 16$, but the majority produced little or no enzyme in the absence of starch. Provided broth cultures were neutralized during growth, the addition of substrate $(1 \% \mathrm{v} / \mathrm{v})$ was followed by increased yield of amylase from both strong-positive and weakpositive strains. In these cultural conditions weak-positive strains whilst 
producing more amylase, were always weak in comparison with strong-positive strains. Doubtful strains were those which gave rise to a few enzyme-positive colonies but which did not produce enzyme in subcultures on starch agar, and liberated no enzyme in starch broth. The total number of amylolytic strains among the 200 strains tested was not altered by growing amylase-negative strains in starch broth; starch agar was the more sensitive medium for the detection of weak activity.

Excluding all 'doubtful' results 73 Group A strains produced amylase. The frequency of amylolytic strains is shown in Table 1, distinguishing strains typed by the $M$ precipitin method from those that could not be so typed and were identified by slide agglutination. Table 2 shows members of closely related specific Types (Stewart, Swift, Wilson \& Lancefield, 1944; Lancefield \& Dole, 1946; Pakula, 1951). Table 3 shows strains belonging to specific Types having single $\mathrm{T}$ antigens.

\section{Table 1. The frequency of amylolytic strains among 200 Group $A$ streptococci}

Amylase $+=$ strains producing enzyme in starch agar cultures. Amylase $-=$ strains producing no enzyme in presence of substrate. $\%=\%$ of total in each category.

\begin{tabular}{|c|c|c|c|c|c|}
\hline \multirow[b]{2}{*}{ Strains } & \multirow[b]{2}{*}{ Nos. } & \multicolumn{2}{|c|}{ Amylase + } & \multicolumn{2}{|c|}{ Amylase - } \\
\hline & & Nos. & $\%$ & Nos. & $\%$ \\
\hline Group A, total & 200 & 73 & $36 \cdot 5$ & 127 & $63 \cdot 5$ \\
\hline $\begin{array}{l}\text { Group A, typed by } M \\
\text { precipitin tests }\end{array}$ & 121 & 25 & $20 \cdot 7$ & 96 & $79 \cdot 3$ \\
\hline $\begin{array}{l}\text { Group } A \text {, typed by slide } \\
\text { agglutination }\end{array}$ & 70 & 43 & $62 \cdot 5$ & 27 & $38 \cdot 5$ \\
\hline Group A, untypable & 9 & 5 & 55 & 4 & 45 \\
\hline
\end{tabular}

The results show that all members of Type 2, and most members of the Group A Types related to 4, elaborated amylase. Less than $20 \%$ of the other Group A strains produced the enzyme, the exceptional strains being found in several different $\mathbf{T}$ antigen groups, and also among strains having single $\mathbf{T}$ antigens. A survey of amylolytic strains among a truly representative collection was not attempted, because these results established that occasional amylolytic strains were likely to be found among members of any specific Type. On the other hand, with regard to Types 2 and 4 , there was a clear indication of relationship between serological Type and amylase-activity.

\section{Anomalies connected with serological typing of amylolytic streptococci}

Sixty-six per cent of amylolytic strains were untypable by $\mathbf{M}$ precipitin tests. The majority of these, on the basis of their hyaluronidase production (Crowley, 1944) and their agglutination reaction, were assigned to Type 4. Though the reaction was weak seven Type 4 strains were typable by the M precipitin reaction. In this connexion it has been pointed out by $\mathrm{Dr}$ R. C. Lancefield and by Mr W. R. Maxted (personal communications) that satis- 


\section{Table 2. The incidence of amylolytic strains among closely related specific Types}

Non-precipitating strains were assigned to different $\mathbf{T}$ antigen groups on results of slideagglutination tests. Type 4 strains produced hyaluronidase. $*$ = Single strains showed weak amylase activity as isolated phenomenon. $M \pm=$ doubtful precipitation.

\begin{tabular}{|c|c|c|c|c|c|}
\hline $\begin{array}{l}\text { T antigen group } \\
\text { of closely } \\
\text { related specific }\end{array}$ & $\begin{array}{l}\text { No. of } \\
\text { strains in }\end{array}$ & $\begin{array}{l}\text { Specific Types of } \\
\text { strains with reactive }\end{array}$ & & No. of & strains \\
\hline Types & group & M protein & Nos. & Amylase + & Amylase - \\
\hline 3, 13. B3264 & 16 & $\begin{array}{l}\text { Type } 3 \\
\text { Type } 13 \\
\text { Non-precipitating }\end{array}$ & $\begin{array}{l}7 \\
6 \\
3\end{array}$ & $\begin{array}{l}\mathbf{0} \\
\mathbf{0} \\
\mathbf{0}\end{array}$ & $\begin{array}{l}7 \\
6 \\
3\end{array}$ \\
\hline $\begin{array}{c}4,24,26,28 \\
29,46\end{array}$ & 40 & $\begin{array}{l}\text { Type } 4 \\
\text { Type } 24 \\
\text { Type } 26 \\
\text { Type } 28 \\
\text { Type } 29 \\
\text { Type } 46 \\
\text { Non-precipitating }\end{array}$ & $\begin{array}{l}7(M \pm) \\
3 \\
1 \\
2(M \pm) \\
1 \\
1 \\
25\end{array}$ & $\begin{array}{r}\mathbf{7} \\
\mathbf{1} \\
\mathbf{0} \\
\mathbf{2} \\
\mathbf{0} \\
\mathbf{0} \\
\mathbf{2 3}\end{array}$ & $\begin{array}{l}0 \\
\mathbf{2} \\
1 \\
0 \\
1 \\
1 \\
1 \\
2\end{array}$ \\
\hline $\begin{array}{c}5,11,12,27, \\
44\end{array}$ & 34 & $\begin{array}{l}\text { Type } 5 \\
\text { Type } 12 \\
\text { Type } 44 \\
\text { Non-precipitating }\end{array}$ & $\begin{array}{r}14 \\
9 \\
2 \\
9\end{array}$ & $\begin{array}{l}\mathbf{0} \\
\mathbf{0} \\
\mathbf{0} \\
\mathbf{2}\end{array}$ & $\begin{array}{c}14 \\
9 \\
2 \\
7 *\end{array}$ \\
\hline 8, 25, Imp 19 & 6 & $\begin{array}{l}\text { Type } 8 \\
\text { Type } 25 \\
\text { Non-precipitating }\end{array}$ & $\begin{array}{l}1 \\
1 \\
4\end{array}$ & $\begin{array}{l}\mathbf{0} \\
\mathbf{0} \\
\mathbf{2}\end{array}$ & $\begin{array}{l}1 \\
1 \\
2\end{array}$ \\
\hline 14, R491 & 11 & $\begin{array}{l}\text { Type 14 } \\
\text { Non-precipitating }\end{array}$ & $\begin{array}{r}10 \\
1\end{array}$ & $\begin{array}{l}\mathbf{0} \\
\mathbf{0}\end{array}$ & $\begin{array}{c}10^{*} \\
1\end{array}$ \\
\hline $\begin{array}{l}15,17,19,23, \\
30,47\end{array}$ & 18 & $\begin{array}{l}\text { Type } 15 \\
\text { Type } 17 \\
\text { Type } 19 \\
\text { Type } 23 \\
\text { Type } 30 \\
\text { Non-precipitating }\end{array}$ & $\begin{array}{l}1 \\
2 \\
5 \\
5 \\
1 \\
4\end{array}$ & $\begin{array}{l}\mathbf{0} \\
\mathbf{0} \\
\mathbf{0} \\
\mathbf{0} \\
\mathbf{0} \\
\mathbf{0}\end{array}$ & $\begin{array}{l}1 \\
\mathbf{2} \\
\mathbf{5} \\
\mathbf{5} \\
\mathbf{1} \\
\mathbf{4}\end{array}$ \\
\hline
\end{tabular}

Table 3. The incidence of amylolytic strains among serological Types having single $T$ antigens

$\mathbf{M}=$ typed by precipitin tests. $*$ =Single strains showed weak activity as isolated phenomenon. All type 22 strains produced hyaluronidase.

\begin{tabular}{|c|c|c|c|c|c|}
\hline \multirow{3}{*}{$\begin{array}{c}\text { Group A } \\
\text { serological type }\end{array}$} & \multirow{2}{*}{$\begin{array}{l}\text { No. of } \\
\text { strains }\end{array}$} & \multirow{2}{*}{\multicolumn{2}{|c|}{$\begin{array}{l}\text { Numbers typable by } \\
M \text { precipitin tests }\end{array}$}} & \multicolumn{2}{|c|}{ No. of strains } \\
\hline & & & & \multirow{2}{*}{$\underset{13}{\text { Amylase }+}$} & \multirow{2}{*}{$\begin{array}{c}\text { Amylase - } \\
.\end{array}$} \\
\hline & 22 & $\mathbf{M}$ & 13 & & \\
\hline & & Non-precipitating & 9 & 9 & . \\
\hline \multirow[t]{2}{*}{22} & 18 & & 4 & . & 4* \\
\hline & & Non-precipitating & & 4 & 10 \\
\hline \multirow[t]{2}{*}{$\mathbf{9}$} & 7 & $\mathbf{M}$ & 3 & . & $\mathbf{3}$ \\
\hline & & Non-precipitating & 4 & 3 & 1 \\
\hline \multirow[t]{2}{*}{6} & 7 & $\mathbf{M}$ & 6 & . & 6* \\
\hline & & Non-precipitating & 1 & . & 1 \\
\hline 18 & $\mathbf{2}$ & $\mathbf{M}$ & 2 & . & $\mathbf{2}$ \\
\hline 31 & 2 & $\mathbf{M}$ & 2 & . & $\mathbf{2}$ \\
\hline 1 & 8 & $\mathbf{M}$ & 8 & $\mathbf{2}$ & 6 \\
\hline
\end{tabular}


factory anti-M sera for certain Types including Types 2, 4, 9, 22, 25, 28 are difficult to prepare. Since amylolytic strains largely belonged to these Types, it seemed possible that the amylolytic property was in some way connected with the difficulty of $M$ precipitin typing.

\section{Multiple agglutination reactions}

In the course of typing the streptococci by slide agglutination a number of anomalous reactions were observed which suggested the possibility that amylolytic strains elaborated a common antigenic substance which reacted with an antibody present in immune rabbit sera prepared with amylolytic or potentially amylolytic strains. Thus two amylolytic strains identified as Type 1 by precipitation, were agglutinated by a serum for Type 2. Similar cross-reactions were observed with amylolytic strains of Types 4 and 22, 4 and 25,22 and 14 and 22 and 9.

\section{Loss of $M$ antigen by amylolytic streptococci}

The physical, chemical and immunological properties of the $\mathbf{M}$ substance have been described by Lancefield and her co-workers (Lancefield, 1940; Lancefield \& Dole, 1946; Lancefield \& Perlman, 1952). The M substance is the labile Type-specific cell antigen of Streptococcus pyogenes which is the major factor contributing to the potential virulence of a strain, and which stimulates protective immunity in the mouse. When extracted from streptococci by boiling the cells at pH 2, the M substance is an alcohol-soluble protein, and its serological activity is destroyed by proteolytic enzymes, notably by trypsin and by a proteinase (Elliott, 1945) produced by Group A streptococci in particular cultural conditions. Two other Type-specific cell components have been found in certain Group A strains which may be mistaken for $M$ antigen, namely the $R$ antigen of Type 28 strains (Lancefield \& Perlman, 1952) and the T substance of Type 2 (Maxted, 1953). Both are heat-stable trypsin-resistant antigens, but either property may be modified by the method of extraction. Certain Types $\mathbf{2}$ and 28 strains may yield $\mathbf{T}$ or $\mathbf{R}$ antigens in acid extracts and small amounts may form heavy flocculent precipitates in homologous Type anti-M serum if this is not specially absorbed. It may be noted here that amylase-positive Types 2 and 28 strains, which were typable by the routine method, contained a cell antigen which was readily extracted by trypsin, though not by pepsin, and also by heating at $100^{\circ}, \mathrm{pH} 7 \cdot 8$. These extracts formed very heavy flocculent precipitates in homologous Type anti-M serum which may have been mistaken for $\mathbf{M}$ antigen. In view of these findings it was necessary to distinguish between strains typable by $M$ precipitin tests and strains having $M$ protein with the properties described by Lancefield. On the other hand, the results obtained for a limited number of amylase-negative strains (Types 1, 5 and 12) which were typed by the routine method, suggest that these contained $M$ protein which was acid-soluble, heat-stable, trypsinsensitive and not extractable by any other method. 
Amylase production by strains of related specific

Types 5, 11, 12, 27, 44

The results in Table 2 show that of the strains representing closely related specific Types 5, 11, 12, 27 and 44, two were amylase-positive and both were untypable by $M$ precipitin tests. In the same connexion tests for amylase were made on twenty-eight strains isolated in one district which were received from the Streptococcal Reference Laboratory. Because these may have been of one strain, and it has not yet been shown that they were not, the strains were omitted from the total 200 representative Group A Types. Table 4 shows that eleven amylase-positive strains were untypable by $\mathbf{M}$ precipitin tests and liberated larger amounts of the inactive proteinase precursor than any of the other strains; the latter produced little or none in Neopeptone broth cultures used for $\mathbf{M}$ typing. Like the Type 5 strains shown in Table 2, the seven strains identified as Type 5 by $M$ precipitin tests were amylase-negative. However, a further seven strains, also without $M$ protein were amylase-negative and of these two were indistinguishable by colony character from the eleven amylolytic strains shown in Table 4.

\section{Table 4. Amylase production by certain strains in the $T$ antigen group of closely related Types 5, 11, 12, 27, 44}

The results of $T$ precipitin tests (Types 5 and 12) were inconclusive. Inactive proteinase precursor ++ , \pm , indicates strain differences in proteolytic activity of filtrates after conversion (Neopeptone broth). Ten amylasepositive cultures were homogeneous, and the eleventh contained less than $40 \%$ of amylolytic variants. The strains were isolated in one district and may be different representatives of the same strain, but this is uncertain.

\begin{tabular}{|c|c|c|c|c|c|}
\hline \multicolumn{2}{|c|}{ Group A strains (28) } & \multirow[b]{2}{*}{ Colony forms } & \multirow{2}{*}{$\begin{array}{l}\text { Amylase-positive } \\
\text { strains }\end{array}$} & \multirow{2}{*}{$\begin{array}{l}\text { Proteolytic } \\
\text { activity in } \\
\text { cultures used for } \\
\text { M typing }\end{array}$} & \multirow{2}{*}{$\begin{array}{l}\text { Inactive pro- } \\
\text { teinase precursor } \\
\text { in same culture }\end{array}$} \\
\hline Agglutinations & M precipitin tests & & & & \\
\hline $5,27,44$ & Type 57 strains & Matt translucent & - & - &,,+ \pm- \\
\hline $5,27,44$ & $\begin{array}{l}\text { Non-precipitating } \\
11 \text { strains }\end{array}$ & Large opaque & 11 & - &,,++++++ \\
\hline $5,27,44$ & $\begin{array}{l}\text { Non-precipitating } \\
7 \text { strains }\end{array}$ & $\begin{array}{l}\text { Variable opaque } \\
\text { and glossy }\end{array}$ & - & - &, \pm- \\
\hline $12,27,44$ & $\begin{array}{l}\text { Non-precipitating } \\
\text { 3 strains }\end{array}$ & Mucoid (stable) & - & - &, \pm- \\
\hline
\end{tabular}

\section{Factors possibly connected with loss of $M$ antigen}

The majority of amylolytic strains were isolated from patients with acute streptococcal infections and on the basis of clinical findings were certainly pathogenic. Three different Type 2 strains, for example, were associated with severe infections. It was possible that streptococci capable of elaborating $M$ antigen in vivo were incapable of doing so outside the host, but there were several other possible factors to be considered. First there was the possibility that the M substance was destroyed by small amounts of proteinase in the same culture. Though amylolytic streptococci produced variable amounts of inactive proteinase precursor (Elliott \& Dole, 1947) there was no evidence that proteinase was present in the cultures used for $M$ typing. Another possibility was that the anti-M typing sera contained insufficient antibody because of 
the difficulty of making satisfactory sera for certain Types which was mentioned on p. 414. The M protein is poorly antigenic at best, and it might be that in the Types most often associated with amylase activity, it was even less effective as an antigen in the rabbit. This anomaly, however, suggested two other ideas, one being that the $M$ antigen was lost from cells because it was all liberated into the culture medium.

According to Olarte (1948) certain Group A strains released reactive M protein in broth cultures. He also found free material in the same cultures which reacted with anti-T sera. Four strains used by Olarte were among the stock cultures tested for amylase (S23/94/2, J17E/100/6, J17 F/38/1, $\mathrm{D} \mathrm{24/42/0)}$ but none of them was amylase-positive. In a preliminary test broth cultures of strain J17/F (Type 26) contained protein which precipitated in unabsorbed homologous Type anti-M serum, and in anti-T serum, but which also reacted strongly with heterologous anti-M and anti-T sera of the closely related specific Types 4, 24, 28, 29 and 46. This suggested that the cultures contained free $\mathbf{T}$ substance, which is shared by these specific Types. The amylolytic strains were, however, different from those used by Olarte, because cellular M protein was not demonstrated.

Another possibility still remained, namely that the $\mathbf{M}$ protein was not lost from the cells in the sense that implies destruction, but that in these streptococci, it underwent a physico-chemical change which rendered it atypical. Early experiments made with a Type 2 strain $(\mathrm{T} 2 / 44 / \mathrm{Rb} 5)$ suggested that amylase was produced by certain matt-opaque colony variants found in blood-agar plate cultures and it seemed possible that the study of this phenomenon might furnish additional evidence about the relationship of amylase production to loss of $\mathrm{M}$ antigen.

\section{Amylase production by variants}

Besides the anomalies noted in connexion with serological typing of the amylolytic streptococci, it was found, as already noted, that about half the amylolytic strains generated mixed populations on starch agar, containing few or many amylase-positive colonies in a background growth of amylasenegative microcolonies. Before exposure to iodine enzyme-positive colonies were identifiable by their size and opacity, and also by faint halos of turbidity corresponding to the achroic zones revealed by iodine. Provided that the culture medium was clear and culture plates contained equal layers of agar there was rarely any difficulty in selecting amylase-positive variants for subculture.

For the study of variants, glutinous corn starch (Amioca) was a more sensitive substrate than ordinary starch. Like other bacterial amylases the streptococcal enzyme resembles $\alpha$-amylase in that it rapidly degrades both amylopectin and glycogen, but has a relatively slight effect on amylose. Amioca contains more than $90 \%$ of amylopectin, and it was therefore a more sensitive substrate than starch for the detection of weak activity. Following exposure to iodine the unchanged substrate was claret-coloured, nearer to the red brown of glycogen than to the purple of non-glutinous corn amylopectin. 
The heterogeneity of amylolytic cultures was not appreciated until suitable broth dilutions (to $10^{-8}$ ) were spread on substrate agar. Nearly all strains generated either greater or lesser numbers of enzyme-negative colonies $(<10 \%$ to $>90 \%$ ). When parent strains formed uniform growth in broth cultures, amylase-positive variants were distributed in decreasing numbers in higher dilutions, but in proportion to the numbers of amylase-positive variants in low dilutions. When strains formed granular broth cultures there were considerable discrepancies, the number of amylase-positive variants being disproportionately small in the higher dilutions. The streptococci deposited at single sites differed so widely in amylolytic power that the conclusion that amylase was produced by variants was inescapable. The same strains growing either on blood agar or plasma agar formed very large colonies in the uncrowded conditions of high dilution. In duplicate cultures on the substrate agar, certain strains gave rise to a few strong-positive variants, a few weakpositive variants, and a predominance of negative colonies. Single amylolytic colonies growing in relative isolation sometimes grew to great size $(2 \mathrm{~mm}$.) in relation to the rest of the population, but colonies which were producing small amounts of enzyme remained small in comparison, when growing in equally favourable conditions. The streptococci which produced the largest amounts of amylase were benefited by the presence of substrate, but the medium while supporting the growth of amylase-negative organisms, did not provide a favourable environment for exacting organisms such as Group A streptococci. The amylolytic property as a single character was first studied in serial subcultures on the same medium, and also in altered cultural conditions.

\section{Transmissibility of the amylolytic property}

Strong-positive amylolytic colonies were broken up in small volumes of Hartley digest broth and $\mathbf{0 . 2} \mathrm{ml}$. of the diluted cell suspension was spread on culture plates. Daily subcultures were made on substrate agar until weakpositive variants or negative colonies predominated in the populations or until the number of positive-variants was less than half the numbers found in the first subculture on starch agar. The results in Table 5 show that in some instances the amylolytic property was transmissible to the progeny of variants for as many as forty subcultures, amounting to a considerable number of generations. Other strains completely lost the property after one or two subcultures, and certain strains generated increasing numbers of weak-positive variants without entirely losing the ability to degrade starch.

The two most stable amylolytic strains among the sixteen shown in Table 4 were stock-cultures, T1/119/5 and T2/opaque, both received from Dr Lancefield. These were then propagated on 'subminimal' starch agar (prepared without Fildes's digest). In second or third subcultures, the populations contained $50 \%$ or more of enzyme-negative colonies but when the two strains were transferred to plasma agar for one or two subcultures, both recovered amylolytic power, which remained unimpaired for many generations in subcultures on the minimal medium. Weak-positive variants generated by strains $\mathrm{T} 2 / 44 / \mathrm{Rb} 5,6068, \mathrm{C} 1010, \mathrm{O} 15104, \mathrm{RZ} 12$ and $\mathrm{RZ} 44$ also completely recovered 
Table 5. The differences in stability of amylolytic variants generated by different Group A strains

\begin{tabular}{|c|c|c|c|c|}
\hline Group A strains & $\begin{array}{l}\text { Precipitin tests } \\
\text { M }\end{array}$ & $\begin{array}{l}\text { Agglutination } \\
\text { pattern }\end{array}$ & $\begin{array}{l}\% \text { of amylase } \\
\text { positive } \\
\text { colonies in } \\
\text { primary culture }\end{array}$ & $\begin{array}{l}\text { Nos. of } \\
\text { subcultures in } \\
\text { which approxi- } \\
\text { mately the same } \\
\% \text { of progeny } \\
\text { were amylase } \\
\text { positive }\end{array}$ \\
\hline T $1 / 119 / 5$ (SF 130/2) & Type 1 & $1,2,4,28,22$ & $>90$ & 46 \\
\hline SR707 & Type 1 & 1,2 & $>90$ & 14 \\
\hline $\mathrm{T} 2 / 44 / \mathrm{Rb} 5$ (SF 22) & Type 2 & 2 & $>80$ & 10 \\
\hline T2/Opaque & Type 2 & 2 & $>90$ & 49 \\
\hline Brook & Type 2 & 2 & 80 & 8 \\
\hline 6068 & Type 2 & 2 & 55 & 6 \\
\hline C1010 & Non-precipitating & 4,24 & 70 & 5 \\
\hline O15104 & Non-precipitating & $4,24,29$ & 76 & 7 \\
\hline SR359 & Non-precipitating & $5,27,44$ & $>90$ & 10 \\
\hline RZ23 & Non-precipitating & $5,12,44$ & $>90$ & 5 \\
\hline RZ12 & Type $25 \pm$ & 8,25 & 90 & 15 \\
\hline RZ44 & Non-precipitating & 22,14 & 85 (60 weak +$)$ & 4 \\
\hline DS21 & Non-precipitating & 22,14 & $84(20$ weak +$)$ & 6 \\
\hline RZ90 & Non-precipitating & 22 & $30(15$ weak +$)$ & 4 \\
\hline SR 1039 & Non-precipitating & 9 & $30(20$ weak +$)$ & 2 \\
\hline SR985 & Non-precipitating & 9 & 10 weak + & 1 \\
\hline
\end{tabular}

amylolytic power after one or two subcultures on plasma agar. The findings were reproducible when the procedure was repeated three or four times for each strain. The procedure was only partly successful in regenerating amylolytic power when applied to weak variants of certain other strains shown in Table 5 (SR 1039, 985, RZ90). It failed when applied to fourteen Group A strains which were originally classified as doubtful amylase producers. Data relating to a total of fifty amylolytic strains indicated that when populations contained less than $30 \%$ of enzyme-positive colonies, the possibility of recovery on plasma agar was limited in comparison with that of strong positive strains. This suggested that certain strains lost the enzymic substance by dilution when grown on subminimal medium but elaborated more enzyme in enriched medium, and the capacity for recovery was a property inherent in the parent strain, and independent of substrate.

The substrate agar was then improved as a culture medium for Group A streptococci in general by addition of increasing amounts of Fildes's digest, crystalline haemin (5-10 $\mu \mathrm{mg} . / \mathrm{ml}$. agar), or peptone (Neopeptone, Proteose peptone, Benger's peptone) and glucose (0.1-1 \%). Benger's peptone $(2 \%$, $\mathrm{v} / \mathrm{v}$ ) or Fildes's digest or haemin provided factors which promoted the recovery of amylolytic power by weak variants. Glucose concentrations greater than $0.3 \%$ promoted growth but inhibited amylase production. Duplicate cultures made on minimal and enriched substrate agar were incubated aerobically, anaerobically and in air containing $5 \%$ carbon dioxide, using six strains shown in Table 4: T1/119/5, T2/opaque, T2/44/Rb5, RZ12, C1010 and RZ90. All of the strains grew better either in anaerobic or carbon dioxide cultures than in air. Because the colonies were larger weak amylase production was 
more easily seen, but the same effect was obtained by prolonging aerobic incubation from 18 to $40 \mathrm{hr}$. at $37^{\circ}$. Thirty amylase-negative Group A strains were then re-tested for amylase production in varied cultural conditions. There was no evidence that the enrichment of the substrate agar induced the production of amylase by strains which were enzyme-negative on the minimal medium.

\section{Amylase production by matt-colony and glossy-colony variants}

Lancefield (1940) noted that among Group A streptococci colonial variation from matt to glossy forms was often associated with changes in antigenic structure. Matt-colony variants of certain strains usually contained M substance which was absent from or reduced in glossy variants. Certain amylolytic strains formed both matt and glossy colonies in plasma agar cultures, while other amylolytic strains growing on the same medium formed large-opaque and small-translucent colony variants. The large-opaque variants of several strains were designated intermediate, signifying a resemblance to the matt-form. When single-colony cultures were made on substrate agar, matt, intermediate and large-opaque variants often gave rise to numerous amylolytic colonies whilst glossy and small variants generated either few or no amylolytic organisms.

Six of the strains shown in Table 5 gave rise to distinct matt-colony and glossy-colony variants: T1/119/5, T2/opaque, RZ23, 6068, Brook and T2/44/Rb5. The antigens of the last two strains were studied by Maxted (1953) who isolated matt and glossy cultures with and without $\mathbf{M}$ antigen. The other four strains were designated 'matt' when first received in the laboratory and glossy-colony variants were isolated from subcultures. Cell suspensions of different colony variants, diluted to contain approximately equal numbers of organisms were seeded on substrate agar plates in serial dilutions for enumeration of amylolytic progeny.

Matt colony cultures were strongly amylase positive; glossy colony cultures were amylase negative, or weakly positive in one instance. Matt strains were then repeatedly subcultured on plasma agar, selecting colony variants which were identical with the parent matt form, and also colonies which differed from the parent in size, opacity or glossiness. Loss of amylolytic power was associated with change of colony form, namely the matt-to-glossy variation, but certain strains gave rise to intermediate and small opaque colonies which showed weakened amylolytic power in comparison with matt variants. Thirtysix amylolytic strains (of which twenty-seven were untypable by $\mathbf{M}$ precipitin tests) showed the same phenomenon, namely the association of amylase production with matt-opaque, large opaque and intermediate colony variants, and the weakening or loss of the property in glossy or near to glossy variants.

\section{Properties of matt-colony cultures in relation to amylase production}

At intervals during subculture matt and glossy strains were tested for Group A polysaccharide, for agglutinating antigens, for proteinase and for its inactive precursor. Cell extracts were prepared (1) by digesting organisms with 
trypsin and pepsin, (2) by heating organisms for different time intervals at $\mathrm{pH} \mathrm{2,} \mathrm{either} \mathrm{at} 37^{\circ}$ or $57^{\circ}$. Matt strains produced larger amounts of the inactive proteinase precursor than glossy strains, and this difference was greater when matt strains were grown in media containing starch. Since these strains produced more amylase, the fermentation of starch was accompanied by a fall in $\mathrm{pH}$ value, and this produced conditions suitable for the release of the precursor (Elliott, 1950). Matt strains, however, also contained large amounts of a cell substance extractable by crystalline trypsin $(0.01 \mathrm{mg} . / \mathrm{ml}$. culture for $6 \mathrm{hr}$., at $37^{\circ}$, at $\mathrm{pH} \mathrm{8.0)}$ which precipitated in homologous Type anti-M serum, and in some instances with certain heterologous Type anti-M and anti-T sera. This substance, which was not successfully extracted by pepsin, also precipitated strongly in proteinase precursor anti-serum, prepared with crystalline precursor and absorbed with crystalline proteinase. Elliott (1950) found that the precursor anti-serum did not react with other streptococcal products, though crystalline precursor reacted with anti-serum prepared with partially purified deoxyribonuclease. The trypsin-extractable substance therefore contained at least two substances, namely the precursor and the material reacting with the type-sera. It also contained amylase. Since glossy strains contained relatively small amounts of the trypsin-extractable substance and produced only small amounts of amylase, it seemed possible that this cell component was associated with the amylolytic power of the matt variants.

The serological activity of the soluble substance was similar to or identical with the agglutination pattern of the strain recorded during slide-agglutination tests. The strain T1/119/5 (SF 130), for example, was agglutinated by antisera for Types 1, 2, 4, 28 and 22, and the material extracted with trypsin precipitated in homologous Type 1 unabsorbed anti-M and anti-T sera, and also in heterologous Type sera, 2, 4 and 28. The strain RZ44, shown in Table 5, was identified by slide agglutination as Type 22, but showed crossreactions with Type 14. Cell extracts reacted with Type 14 unabsorbed anti-M sera, and also with anti-T sera Types 14 and 22. The material extracted by trypsin during $6 \mathrm{hr}$. was presumably resistant to digestion by trypsin and was therefore like $\mathbf{T}$ antigen. However, the yield of reactive material obtained by digesting the organism with pepsin was negligible in comparison, which was unlike $\mathrm{T}$ antigen (Lancefield \& Dole, 1946). When $6 \mathrm{hr}$. extracts (pH 7.8), still containing trypsin, were freed from cells and the filtrates were re-incubated overnight at $37^{\circ}$, the reactivity with proteinase precursor antiserum was not significantly altered, but both amylase activity and reactivity with Type sera were destroyed. The free substance was therefore trypsin sensitive, which was also unlike $\mathbf{T}$ antigen. Slow inactivation took place at bench temperature or at $37^{\circ}$ in the absence of trypsin. When cell-free extracts were re-incubated at $37^{\circ}$ with $1 \%$ glutinous corn starch the reactivity with homologous Type anti-M and anti-T sera was not destroyed. 


\section{Trypsin-extractable substance from strain $R Z 44$, Type 22}

Organisms were harvested from $3.5 \mathrm{l}$. of $24 \mathrm{hr}$. broth culture (Neopeptone infusion broth) of strain RZ44. The cells were washed 4 times in buffer, and the centrifuged sediment suspended in buffer $\mathrm{pH} \mathrm{7.8}$ containing crystalline trypsin $0.01 \mathrm{mg}$. $/ \mathrm{ml}$. The suspension was incubated for $6 \mathrm{hr}$. at $37^{\circ}$. The supernatant was made cell-free by filtration. The crude extract $(100 \mathrm{ml}$.) reacted with Type 14 anti-M serum and proteinase precursor anti-serum to a titre of 1/64 (antigen diluted). The Type 14 serum had been previously absorbed with an M extract of heterologous Type.

The reactive protein was soluble in slightly acidified $70 \%$ ethanol but precipitated by $80 \%$ ethanol at $\mathrm{pH} 7 \cdot 4$ or higher $\mathrm{pH}$ values, therefore it was further purified by fractional precipitation with cold ethanol discarding substances insoluble in 25,50 and $70 \%$ ethanol in the $\mathrm{pH}$ range $7 \cdot 0-5 \cdot 6$. The reactive protein then precipitated from the supernatant by $80 \%$ ethanol at $\mathrm{pH} \mathrm{8.0} \mathrm{was} \mathrm{part} \mathrm{crystalline} \mathrm{and} \mathrm{part} \mathrm{amorphous,} \mathrm{and} \mathrm{was} \mathrm{further} \mathrm{purified} \mathrm{by}$ reprecipitation at $\mathrm{pH} 2.5$ following the method used by Lancefield \& Dole (1946) to purify $\mathrm{T}$ antigen. After five precipitations, the protein crystallized in $90 \%$ ethanol at $\mathrm{pH} 8$, and was then crystallized six times in ethanol. The final product precipitated in Type 14 anti-M serum and proteinase precursor antiserum; the results of precipitin tests are shown in Table 6. A single absorption with the purified antigen removed the precipitating antibody from the Type 14 anti-M and precursor antisera, but did not remove either the $\mathbf{M}$ antibody from the one, or the precursor antibody from the other.

The strain RZ44 liberated large amounts of a similar reactive protein into culture media containing substrate, which, after purification and crystallization by the same procedure was serologically identical with the cell substance. The purified free protein was antigenic in the rabbit. The immune serum precipitated the homologous free antigen, the homologous cell antigen, and the crystalline proteinase precursor. A single absorption either with the free antigen or the cell antigen removed the precipitating antibody, which was not however, completely removed by absorption with the crystalline precursor. The purified antigens contained amylase but it is still uncertain if the enzyme is identical with, part of, or derived from the antigen.

\section{DISCUSSION}

Among haemolytic streptococci of human origin, amylase-producing strains have at present been found only among members of Group A. Trypsinresistant cell antigens related to Group A serological Types have been found in Groups B, C and G strains, namely the $\mathbf{R}$ antigen of Type 28 (Lancefield \& Periman, 1952) and the $T$ antigen of Type 2 (Maxted, 1953). Hyaluronidaseproducing Groups $\mathrm{C}$ and $\mathrm{G}$ strains which were specifically agglutinated by Group A antisera for Types 2, 5, 25 and 28 were found by Crowley (1944). The Type 22 antigen, which with Type 4 is associated with hyaluronidase activity in Group A, has not yet been reported in connexion with other serological groups. Serological Types, therefore, which are associated with 


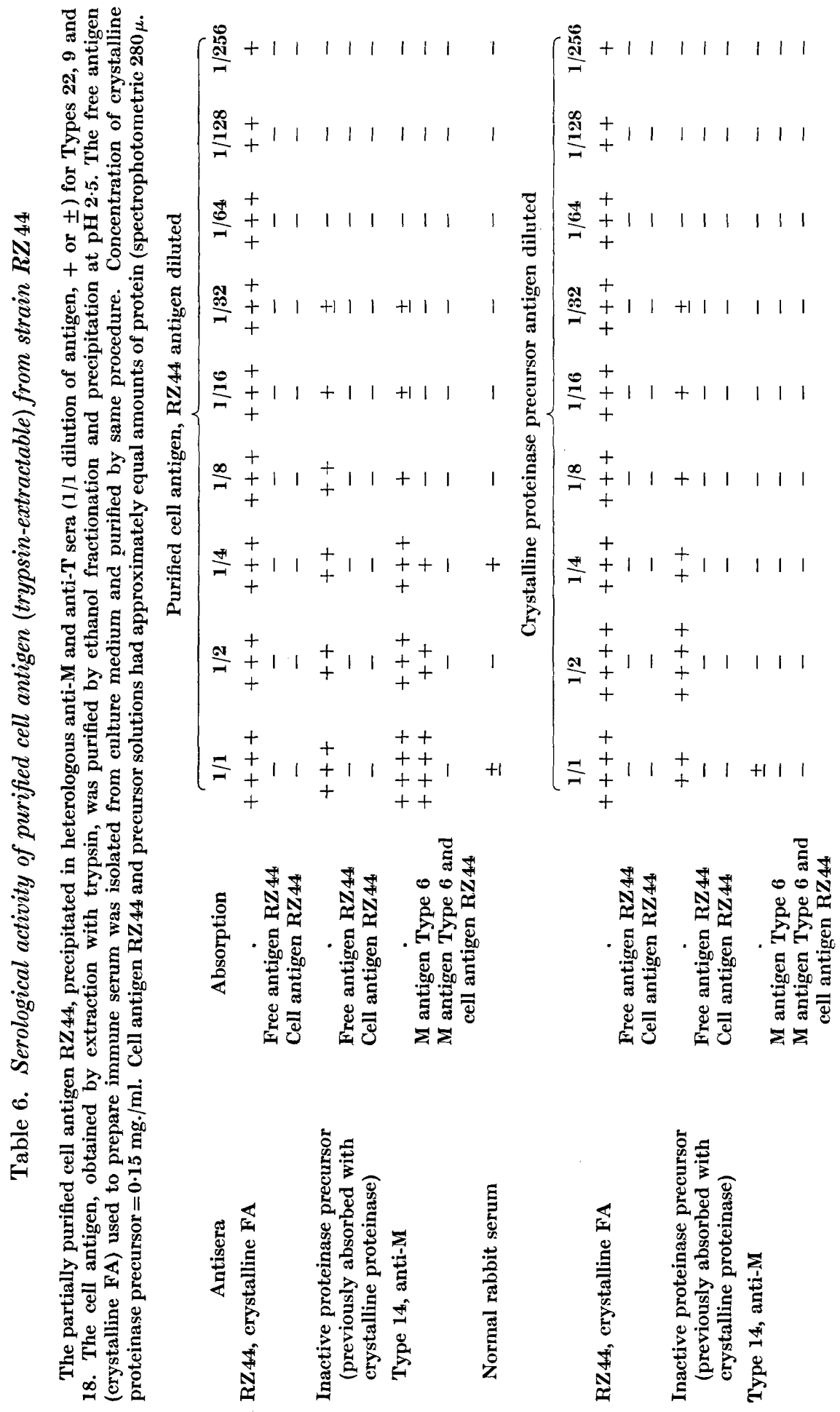


amylolysis in Group A, are also associated with phenomena in Groups C and G, namely the presence of trypsin-resistant cell antigens and the production of hyaluronidase. There was, however, no strict correlation between the presence of the cell antigen and the ability to elaborate the enzymes. If the amylase is a Group A specific substance, which requires further confirmation, it may be possible that the presence of certain T- or R-like factors may confer trypsinresistance on a cellular component derived from or related to the $M$ antigen. The purified proteins in the instance described had physical and chemical properties similar to those of $\mathbf{M}$ antigen, namely alcohol-solubility, heatresistance and trypsin-sensitivity. The cell antigen was however extracted by trypsin, following the method used to extract $\mathbf{R}$ antigen and, though unlike $T$ antigen it was not extractable by pepsin, the substance was purified by the method used by Lancefield \& Dole (1946) to purify $\mathrm{T}$ antigen.

At present the amylolytic substance cannot be equated with $\mathbf{M}, \mathbf{T}$ or $\mathbf{R}$ antigen on the basis of physico-chemical or immunological properties. The interpretation of the serological findings depends on the purity of the antigens and the antibody content of the sera. Elliott (1950) suggested that the inactive proteinase precursor may be part of a larger molecule. It seems possible that the amylase and the precursor may be released from the cell as part of such a molecule derived from, or related to, the $\mathrm{M}$ and $\mathrm{T}$ antigens of the present strains.

It was pointed out by Stanier (1953) that a phenomenic property singled out for study as a character may be an incidental by-product conferring other essential properties on the organism. Amylolytic strains are enabled to survive in an environment unfavourable for Group A strains in general; the by-product confers this essential property on the organisms. The ability to confer stable amylolytic power on the progeny was associated with the possession of a cell antigen, and with the ability of the present strain to remain matt or near to matt. The maintenance of this phase may depend on the degree of resistance of the cell antigen, to proteolytic digestion. This may also be a factor regulating the rate of its release from the cell.

I wish to thank the Director and staff of the Streptococcal Reference Laboratory for supplying the majority of the strains.

\section{REFERENCES}

Crowley, N. (1944). Hyaluronidase production by haemolytic streptococei of human origin. J. Path. Bact. 56, 27.

Crowley, N. (1950). The degradation of starch by Group A streptococci having related antigens. J. gen. Microbiol. 4, 156.

Ellrotr, S. D. (1945). A proteolytic enzyme produced by Group A streptococci with special reference to its effect on the type specific $M$ antigen. J. exp. Med. 81, 573.

Elliotr, S. D. (1950). The crystallisation and serological differentiation of a streptococcal proteinase and its precursor. J. exp. Med. 92, 201.

ElliotT, S. D. \& Dole, V. P. (1947). An inactive precursor of streptococcal proteinase. J. exp. Med. 85, 305.

Griffith, F. (1934). The serological classification of Streptococcus pyogenes. J. Hyg., Camb. 34, 542. 
Lancefield, R. C. (1940). Type-specific antigens $M$ and $T$, or matt and glossy variants of Group A streptococci. J. exp. Med. 71, 539.

Lancefield, R. C. \& Dole, V. P. (1946). The properties of T antigens extracted from Group A streptococci. J. exp. Med. 84, 449.

Lancefield, R. C. \& Perlman, G. E. (1952). Preparation and properties of a protein ( $R$ antigen) occurring in streptococci of Group A, Type 28 and in certain streptococci of other serological groups. J. exp. Med. 96, 83.

Maxted, W. R. (1948). Preparation of streptococcal extracts for Lancefield grouping. Lancet ii, 255.

Maxted, W. R. (1958). The $M$ and $T$ antigens of streptococcus pyogenes Type 2. J. Path. Bact. 65, 345.

McClean, D. (1942). The in vivo decapsulation of streptococci by hyaluronidase. J. Path. Bact. 54, 284.

Olarte, J. (1948). Demonstration of the ' $M$ ' protein in culture filtrates of haemolytic streptococci of Group A. J. Immunol. 58, 15.

Pakula, R. (1951). Extraction of the T antigen of Streptococcus pyogenes. J. gen. Microbiol. 5, 640.

Stanier, R. Y. (1953). Adaptation, evolutionary and physiological; or Darwinism among the micro-organisms. Symp. Soc. gen. Microbiol. 3, 1.

Stewart, W. A., Swift, H., Wilson, A. \& Lancefield, R. C. (1944). Studies on the antigenic composition of Group A haemolytic streptococci. IV. Related T but distinct $M$ antigens in Types 15, 17, 19, 23, 30 and in Types 4, 24, 26, 28, 29, 46. Identification by slide agglutination. J. exp. Med. 79, 99.

Swift, H., Wilson, A. \& Lancefield, R. C. (1943). The typing of Group A streptococci by $M$ precipitin reactions in capillary pipettes. J. exp. Med. 78, 127.

Todd, E. W. \& HewitT, L. (1932). A new culture medium for the production of antigenic haemolysin. J. Path. Bact. 95, 873. 